\title{
Quality of care provided to children with cerebral palsy, Alexandria, Egypt
}

Mona Khalil ${ }^{1}$, Heba Elweshahy ${ }^{2}$, Hayam Abdelghani ${ }^{3}$, Tarek Omar ${ }^{1}$ and Samia Ahmed ${ }^{1}$

Department of Paediatrics, Faculty of Medicine, Alexandria University, Alexandria, Egypt (Correspondence to: Mona Khalil: drmonakhalil@yahoo. com). ${ }^{2}$ Department of Community Medicine and Public Health, Faculty of Medicine, Alexandria University, Alexandria, Egypt. ${ }^{3}$ Department of Physical Medicine, Rheumatology and Rehabilitation, Faculty of Medicine, Alexandria University, Alexandria, Egypt.

\begin{abstract}
Background: Assessing the quality of care has become increasingly important to health care providers, regulators and purchasers of care.

Aims: This study assessed the quality of care provided to children with cerebral palsy attending Alexandria University Children's Hospital, Egypt.

Methods: Paediatric neurology residents $(n=15)$ who provided care to children with cerebral palsy at the hospital completed a structured checklist assessing their compliance with generic care standards. The medical records of 84 children with cerebral palsy who received care at the hospital were reviewed using the same checklist. Another checklist was completed by the head of the paediatric neurology unit, medical director of the hospital, head of physical medicine and head nurse to assess adherence to process and service improvement standards. Face-to-face interviews were conducted with the caregivers/parents of the children using a client satisfaction questionnaire.

Results: Based on what was reported by health care providers, most did not adhere to the recommended practices in the care of children with cerebral palsy. Review of the medical records also showed a lack of compliance with standards. The mean total satisfaction percentage score of parents/caregivers was 55.43\% (SD 18.16). Satisfaction was particularly low for waiting time, waiting area and availability of required facilities for their child's care.

Conclusions: There is a wide gap between the actual care provided to children with cerebral palsy and the recommended standards. Moreover, the documentation system in the hospital is poor. A quality improvement plan is needed for the provision of care to children with cerebral palsy.
\end{abstract}

Keywords: Cerebral palsy, Child care, Standard of care, Hospitals, Egypt

Citation: Khalil M; Elweshahy H; Abdelghani H; Omar T; Ahmed S. Quality of care provided to children with cerebral palsy, Alexandria, Egypt. East Mediterr Health J. 2018;24(6):522-531. https://doi.org/10.26719/2018.24.6.522

Received: 03/11/16; accepted: 30/03/17

Copyright (C) World Health Organization (WHO) 2018. Some rights reserved. This work is available under the CC BY-NC-SA 3.o IGO license (https:// creativecommons.org/licenses/by-nc-sa/3.o/igo).

\section{Introduction}

Cerebral palsy is the most common cause of motor disability in childhood $(1,2)$. It accounts for $60 \%$ of severe motor disabilities in school-aged children (3). The prevalence of cerebral palsy is around 1.5-3 per 1000 live births in both developed and developing countries (4-6). Differences in prevalence may be due to differences in the characteristics of the populations studied or may also be the result of variations in identifying cerebral palsy cases because of inconsistency in the definition and classification of the condition. A study in Egypt reported a prevalence of 2.04 per 1000 live births among children in Al-Karga District, New Valley Governorate (7). Another study in AlQuseir City, Red Sea Governorate reported a prevalence in children of 3.06 per 1000 live births (8).

Assessment of children with cerebral palsy is best performed by a multidisciplinary team. Management aims at minimizing disability, improving quality of life and encouraging participation in society (9).

The demands of caring for a child with cerebral palsy are considerable, and parents have to deal with the continuously changing needs of their child. Disabilities associated with cerebral palsy affect children's independence and hence the lives of their caregivers. Caring for a child with cerebral palsy can negatively affect parent's physical and psychological health, social relationships, and financial situation. However, the quality and type of care given to children with cerebral palsy are likely to affect the resultant disability, and the quality of their lives and that of their families $(10,11)$.

Measuring the quality of care has become increasingly important to health care providers, administrators, managers and policy-makers. Data from assessment of quality of care should be applied to improve the delivery of care and patient outcome (12,13). Explicit methods of measuring quality of care should be based on reliable, valid and standardized tools. Quality measures are usually categorized into structure, process and outcome measures. Structure and process measures are based mainly on the availability of standards of care and/or quality indicators (13).

The present study was conducted to assess the quality of care provided to children with cerebral palsy attending the Alexandria University Children's Hospital, Egypt. 


\section{Methods}

\section{Study design and setting}

This was a cross-sectional study conducted at Alexandria University Children's Hospital, Egypt within its affiliated Paediatric Neurology Outpatient Clinic and Physical Medicine and Rehabilitation Clinic. The hospital provides care for children with cerebral palsy, including management of acute conditions, inpatient services, rehabilitation and follow-up care. The field work was carried out between 1 February and 30 April 2014.

\section{Participants}

The study included the following participants.

- Fifteen paediatric neurology residents working at Alexandria University Children's Hospital for more than 1 year and directly involved in the care of children with cerebral palsy.

- The Head of the Paediatric Neurology Unit, Medical Director of the Hospital, Head of Physical Medicine and Head Nurse of the Paediatric Neurology Department at Alexandria University Children's Hospital.

- Parents/caregivers of all children with cerebral palsy attending Alexandria University Children's Hospital during the period 1 February to 30 April 2014 (88 children).

\section{Data collection}

Health Care Improvement Scotland developed standards for care of children and young people who are experiencing difficulties that could be related to their mental health, known as integrated care pathways (ICPs) for mental health (14). The standards have 3 elements: process standards, generic care standards and service improvement standards (21 standards).

Process standards (9 standards) outline the infrastructure that must be in place in order to provide high quality care, the key tasks to be undertaken and who is responsible. Generic care standards (10 standards) describe the interactions and interventions that must be offered to anyone who accesses specialized child and adolescent mental health services. Service improvement standards (2 standards) ensure that ICPs are being implemented and actively used for data capture and variance analysis, leading to service improvements. Each standard includes a number of criteria to be fulfilled (14).

We developed a structured checklist of statements included in the process and service improvement standards in the ICPs that were relevant to the service provided to children with cerebral palsy in Egypt and best fit the culture, resources, and economic and administrative situation in Egypt. The checklist consisted of 19 statements with 3 possible answers (not met, partially met or fully met). It was completed by the Head of Paediatric Neurology Unit, Medical Director of the Hospital, Head of Physical Medicine and the Head Nurse of the Paediatric Neurology Department to assess the degree of adherence to process and service improvement standards.

A second checklist was designed based on the criteria of generic care standards in the ICPs. It included 33 statements divided into 4 domains, which related to standards of: care assessment (16 items), care planning (8 items), care delivery (5 items) and outcome (4 items). Each statement had 2 options, usually done or rarely done. This checklist was completed by the 15 paediatric neurology residents; none declined to participate.

The medical records of all children with cerebral palsy who regularly attended the paediatric neurology outpatient clinic $(n=84)$ were reviewed to assess their completeness according to the generic care standard using the same checklist filled by the paediatric neurology residents. Each item was marked as recorded or not recorded in the medical records.

Face-to-face interviews were held with the parents/ caregivers of 88 children with cerebral palsy (the 84 whose records were reviewed and 4 other children who had no medical records at the clinic as they had just started coming to the clinic). None declined to participate. Education, marital status and working status of the caregivers were recorded. They were asked a general question about their overall satisfaction with the services provided at the hospital for their children. In addition, a structured client satisfaction questionnaire, consisting of 8 items, was used to assess their degree of satisfaction with specific aspects of the services: waiting time, waiting area, availability of facilities, number of days the services are available, cost of services, time allowed to discuss problems with care providers and the adequacy of the explanation received.

\section{Data analysis}

Data were coded and entered in Microsoft Excel. Descriptive statistical were mainly used. Numbers and percentages were used for conformity with generic care standards as reported by the residents and as documented in the medical records reviewed.

Range, mean and standard deviation (SD) for the total score for conformity to generic care standards was calculated twice - as reported by the residents and as documented in the medical records reviewed. Items that were not done or not recorded were scored zero and those that were always done or recorded were scored 1.

Parents' satisfaction was analysed using number and percentage as well as by calculating the total raw and percentage score for every parent (by giving a score of o for unsatisfied, 1 for uncertain and 2 for satisfied), and then calculating the mean satisfaction percentage score. The question about their overall satisfaction with the services provided at the hospital for their children was not included in the calculation of the total satisfaction score. Analysis of variance and Student t-test were used to examine the relationship between the mean satisfaction percentage score and caregiver characteristics, after testing for normality (Shapiro-Wilk test) and homogeneity of variances. A P-value $\leq 5$ was considered statistically significant. 


\section{Ethical considerations}

Approval for this study was obtained from the Research Ethics Committee of the Alexandria Faculty of Medicine. Verbal and written consent was obtained from all participants in the study after explaining the aim and procedures of the study. Complete confidentiality was ensured: the data were collected only by the researchers and no one else had access to them.

\section{Results}

\section{Conformity to process and service improvement standards}

Table 1 shows the conformity to process and service improvement standards as rated by the Head of the Paediatric Neurology Unit, Medical Director of the Hospital, Head of Physical Medicine and the Head Nurse in the

Table 1 Conformity to process and service improvement standards for care provided to children with cerebral palsy (CP) as reported by senior hospital managers

\begin{tabular}{|c|c|c|}
\hline Not met & Partially met & Fully met \\
\hline $\begin{array}{l}\text { There are systems in the hospitals to record diagnostic } \\
\text { and/or assessment information which allow for the } \\
\text { recording of multiple values. }\end{array}$ & $\begin{array}{l}\text { A named strategic lead and integrated pathway } \\
\text { coordinator are present in the hospital for } \\
\text { implementing a multiagency and multidisciplinary } \\
\text { plan. }\end{array}$ & $\begin{array}{l}\text { The relationship between local } \\
\text { governance arrangement and } \\
\text { integrated care pathways for } \\
\mathrm{CP} \text { children in hospital can be } \\
\text { demonstrated. }\end{array}$ \\
\hline $\begin{array}{l}\text { The multi-agency and multi-disciplinary care team } \\
\text { reviews individual and grouped variances. }\end{array}$ & $\begin{array}{l}\text { Multiagency and multidisciplinary work forces } \\
\text { (including advocacy services and voluntary } \\
\text { organizations) are involved in the care pathway } \\
\text { development process. }\end{array}$ & $\begin{array}{l}\text { There is a local plan which includes } \\
\text { details of how the hospital will } \\
\text { deliver care for the children with } \\
\mathrm{CP} \text { who are accessing services for } \\
\text { the first time or who are currently } \\
\text { accessing services. }\end{array}$ \\
\hline $\begin{array}{l}\text { A survey of care providers for children with } \mathrm{CP} \text { is } \\
\text { conducted at least annually and the survey results acted } \\
\text { upon. }\end{array}$ & $\begin{array}{l}\text { Children with } \mathrm{CP} \text { and their parents/carers are } \\
\text { involved in the care pathway development process. }\end{array}$ & $\begin{array}{l}\text { There is a secure system in place } \\
\text { that allows for the recording of, and } \\
\text { access to, information in the child's } \\
\text { care record. }\end{array}$ \\
\hline
\end{tabular}

A survey of children with $\mathrm{CP}$ and their parents/carers about care they have received is conducted at least annually and the survey acted upon.
System is in place for awareness-raising, promotion and education sessions about the care pathway.

A process mapping exercise is carried out for : Identification of current patterns of service delivery and available resources

Evaluation of the journey of care of children with CP Establishment of the strengths and weakness of current service provision

Identification of demands on the service. Identification of gaps in services.

A local plan which includes timescales for the children with CP is developed and agreed

There are systems in place to monitor and demonstrate that the training and supervision needs of care providers for children with $\mathrm{CP}$ are acted upon and actively promoted

There are systems in place to ensure that these training and supervision needs and requirements are incorporated into the hospital development plans.

There are systems in place to record the number of children with $\mathrm{CP}$ accessing the hospital services.

Information is recorded and transferred in accordance with current recommendations on consent, confidentially and record-keeping standards.

There are systems in place for recording, collating, analysing, reporting and acting upon variances for children with $\mathrm{CP}$.

The local management team reviews grouped variance to identify areas where service re-design can improve service delivery. 
neurology department. The majority of process and service improvement standards were not fully met (either totally unmet or only partially met) except for 3 standards: presence of a local plan with details of how the organization will deliver care for the children with cerebral palsy who are accessing services for the first time or who are currently accessing services; availability of a secure system that allows the recording of and access to information in the child's care record; and demonstrated relationship between local governance arrangements and ICP for children with cerebral palsy in hospital.

Standards that were totally unmet at the hospital included: lack of a system to monitor care providers of children with cerebral palsy and demonstrate that their training and supervision needs are acted upon and actively promoted; lack of an annual survey of children with cerebral palsy and their parents/carers about care they have received.

\section{Conformity to generic care standards as reported by health care providers}

Table 2 shows the reported adherence to the generic care standards of the 15 health care providers (residents) who were directly involved in the care of children with cerebral palsy at Alexandria University Children's Hospital.

Care assessment standards. During the initial assessment, developmental history is taken by most of the providers $(80 \%)$, and $73 \%$ take a history of past and current interventions. Two thirds of the care providers reported that they usually assess the child for the presence of other associated co-morbidities. A schedule of routine visits for the child was reported by $73 \%$ of the providers. The majority of the providers reported that information on how the diagnosis of cerebral palsy was reached was not recorded and there was no cooperation with other agencies in the process of care. Only 33\% of the care providers said they explained the diagnosis of cerebral palsy to the parents and none of them provided educational, social and lifestyle information and guidance to the parents.

Care planning standards. Two thirds of the providers reported that they recorded the timing of the child's reviews and $53 \%$ of them reported that the child's care plan was planned and agreed with parents/caregivers. Only 33\% reported that the child care plan was based on multidisciplinary assessment, and its specific goals were identified. None of the providers recorded the child's care plan or his/her treatments and interventions in the child health record.

Care delivery standards. Regarding care delivery, particularly for children admitted as inpatients, 33\% documented the reasons for admission in the child's follow-up record and $13 \%$ recorded the aim of the admission. Only $7 \%$ of the health care providers recorded the plan for discharge and length of inpatient stay.

Care outcomestandards. Less than a half of the providers (47\%) said they identified and recorded what had improved or what had got worse in the child's condition, and what aspects of the plan had been changed. All the care providers rarely recorded whether the planned outcomes were achieved or not.

\section{Conformity to generic care standards as found in health care} records

Our review of the health care records of 84 children with cerebral palsy to assess their conformity to the generic care standards are shown in Table 2.

Care assessment standards. In nearly all records, the diagnosis of cerebral palsy was documented. The majority of records $(87 \%)$ included data on associated co-morbidities, and the developmental history of the child was noted in $63 \%$ of the records. On the other hand information on how the diagnosis of cerebral palsy was reached and the current and past interventions were documented in only $21 \%$ and $19 \%$ of the records respectively. Information given to the parents about cerebral palsy, and guidance and advice to them were noted in $20 \%$ of the records. The records do not include any system to record parents' disagreement with the child's care plan. No consent form signed by parents for the care and treatment was present.

Care planning standards. The timing of reviews was clear in only $44 \%$ of the records, while the specific goals of the care were identified in $98 \%$ of records. The child's care plan was documented in $59 \%$ of records.

Care delivery standards. The decision-making process, including when to start, review, maintain or end medications, and their side-effects were noted in $2 \%$ of the records. Few records contained data about the reasons and aims of inpatient admission (2\%) and none had information about the actual length of stay. The plan for discharge was identified in $34 \%$ of the records.

Outcome standards. Only $20 \%$ of the records contained information about whether the planned outcome have been achieved or not. In addition, $33 \%$ and $1 \%$ of the records respectively documented what had improved and what had become worse in the child's conditions. The aspects of the child care that had been changed were identified in only $7 \%$ of the records.

\section{Conformity scores}

Table 3 shows the scores for conformity to the standards in the 4 care areas as reported by the health care providers and found in our review of the children's health records.

As reported by the health care providers, scores for care assessment standards ranged from 2 to 10 with a mean of 6.53 (SD 2.95). For care planning standards, out of 8 points, the mean score was 2.0 (SD 1.36). Scores ranged from 0 to 3 in both care delivery and outcome standards with a mean of 1.27 (SD 0.88) and 1.40 (SD 1.35) respectively.

Based on the review of the children's records, scores for care assessment standards ranged from 2 to 10 with a mean of 4.71 (SD 2.13). For care planning standards, the mean score was 2.52 (SD 1.61). Scores ranged from 0 to 3 for both care delivery and outcome standards with means of 0.45 (SD 0.59) and 0.89 (SD 1.13) respectively. 
Table 2 Conformity to generic care standards as reported by health care providers and found in the review of the health care records of the children with cerebral palsy

\begin{tabular}{|c|c|c|}
\hline Standards of care & $\begin{array}{l}\text { Reported as usually } \\
\text { done }(n=15) \\
\text { No. }(\%)\end{array}$ & $\begin{array}{l}\text { Recorded in the child's } \\
\text { health file }(n=84) \\
\text { No. }(\%)\end{array}$ \\
\hline \multicolumn{3}{|l|}{ Care assessment standards } \\
\hline History is taken on personal, family and social circumstances & $7(47)$ & $24(29)$ \\
\hline Developmental history is taken & $12(80)$ & $53(63)$ \\
\hline $\begin{array}{l}\text { History of current and past interventions (including outcomes, adverse reactions, side-effects) } \\
\text { is taken }\end{array}$ & $11(73)$ & $16(19.0)$ \\
\hline A consent form is signed by parents/caregiver for care and treatment & $1(7)$ & $\mathrm{o}(\mathrm{o})$ \\
\hline The needs of the child and parents/caregivers are recorded & $7(47)$ & $9(11)$ \\
\hline Additional vulnerabilities and co-morbidities are assessed and recorded & $10(67)$ & $72(86)$ \\
\hline Educational, vocational status is recorded & $4(27)$ & $7(8)$ \\
\hline Time for completion of holistic assessment is recorded & $6(40)$ & $12(14)$ \\
\hline Schedule of routine visits is recorded & $11(73)$ & $84(100)$ \\
\hline The diagnosis of cerebral palsy and other diagnoses is recorded & $8(53)$ & $82(98)$ \\
\hline Information on how the diagnosis of cerebral palsy was reached is recorded & $5(33)$ & $18(21)$ \\
\hline Diagnosis of cerebral palsy is explained to the parents & $5(33)$ & $2(2)$ \\
\hline Appropriate information about cerebral palsy is given to the parents in writing & $4(27)$ & $0(0)$ \\
\hline There is cooperation with other partner agencies & o & 0 \\
\hline The care plan of the child is structured & $7(47)$ & $8(10)$ \\
\hline $\begin{array}{l}\text { Information and guidance (including educational, social and lifestyle advice) are provided to } \\
\text { the parents }\end{array}$ & o (o) & $17(20)$ \\
\hline \multicolumn{3}{|l|}{ Care planning standards } \\
\hline $\begin{array}{l}\text { Appropriate advice is provided to parents about available voluntary organizations and } \\
\text { advocacy services }\end{array}$ & $1(7)$ & $9(11)$ \\
\hline The child care plan is planned and agreed with parents/care givers & $8(53)$ & $18(21)$ \\
\hline The timings of review & $10(67)$ & $37(44)$ \\
\hline $\begin{array}{l}\text { The other agencies are involved in child's care and support and information is shared with } \\
\text { them } \\
\text { The child care plan is based on multidisciplinary assessment of strengths of the rehabilitation } \\
\text { process, needs and past experiences }\end{array}$ & $5(33)$ & $11(13)$ \\
\hline The care plan of the child is clear & $0(0)$ & $49(59)$ \\
\hline The child care plan identifies the specific goals of the child in relation to his/her condition & $5(33)$ & $82(98)$ \\
\hline The child's tasks, treatments and interventions are identified in the care plan of the child & $\mathrm{o}(0)$ & $50(60)$ \\
\hline \multicolumn{3}{|l|}{ Care delivery standards } \\
\hline When to initiate, review or end medication and recording of their side-effects & $10(67)$ & $2(2)$ \\
\hline Reasons for inpatient admission are recorded & $5(33)$ & $2(2)$ \\
\hline Aims of admission are recorded & $2(13)$ & $0(0)$ \\
\hline Expected and actual length of inpatient stay are recorded & $1(7)$ & $0(0)$ \\
\hline Plan for discharge is recorded & $1(7)$ & $29(34)$ \\
\hline \multicolumn{3}{|l|}{ Outcome standards } \\
\hline What has improved in the child's condition is recorded & $7(46)$ & $28(33)$ \\
\hline What has become worse in the child's condition is recorded & $7(47)$ & $1(1)$ \\
\hline Achievement of the planned outcomes is recorded & o (o) & $17(20)$ \\
\hline Aspects of the plan that have been changed are recorded & $7(47)$ & $6(7)$ \\
\hline
\end{tabular}


Table 3 Scores for conformity to standards in the 4 areas of care in the generic care standards

\begin{tabular}{lcccc} 
Area of care & \multicolumn{2}{c}{$\begin{array}{c}\text { Reported by health care providers } \\
\text { Range of scores }\end{array}$} & $\begin{array}{c}\text { Mean score } \\
\text { (SD) }\end{array}$ & $\begin{array}{c}\text { Review of records } \\
\text { Rean score (SD) }\end{array}$ \\
\hline Care assessment standards (16 items) & $2-10$ & $6.53(2.95)$ & $2-10$ & $4.71(2.13)$ \\
Care planning standards (8 items) & $0-4$ & $2.0(1.36)$ & $0-7$ & $2.52(1.61)$ \\
Care delivery standards (5 items) & $0-3$ & $1.27(0.88)$ & $0-3$ & $0.45(0.59)$ \\
Outcome standards(4 items) & $0-3$ & $1.40(1.35)$ & $0-3$ & $0.89(1.13)$ \\
\hline
\end{tabular}

$S D=$ standard deviation.

\section{Satisfaction of parents/caregivers with the care provided}

All interviewed caregivers were mothers. Table 4 shows the satisfaction of the mothers with the care provided. Only 37\% said they were satisfied with the services provided at the hospital for their children; $2 \%$ were unsatisfied and $61 \%$ were uncertain. Satisfaction was particularly low for waiting time, waiting area and availability of required facilities for their child's care. About two thirds of the mothers $(64 \%)$ were satisfied with the cost of services. Only $28 \%$ were satisfied with the amount of explanation received about their child. The total satisfaction percentage score ranged from o to $94 \%$ with a mean of $55.4 \%$ (SD $18.2 \%$ ) and a median of $55.7 \%$.

Table 5 shows the mean satisfaction percentage score of the mothers in relation to their sociodemographic characteristics (education, marital status and working status). No statistically significant associations between the score and sociodemographic characteristic were found.

\section{Discussion}

Children with developmental disabilities are likely to experience unmet service needs, which will affect them and their families $(15,16)$. Integrated care plans across all agencies involved in caring for children with cerebral palsy are essential in providing high quality care. A plan should contain general principles of care agreed by all members in the decision-making team and adapted to fit the local context taking into consideration differences in culture, educational levels of parents/caregivers, availability of trained health care providers and local resources (17).

In our study, from the perspective of head managers in the hospital involved in the care of children with cerebral palsy, the hospital lacked a named strategic lead and a coordinator for implementing a multiagency and multidisciplinary plan. Moreover, a lack of multiagency and multidisciplinary work forces involved in the care pathway development process was also reported.

At the centre of the decision-making team are the parents of the child with cerebral palsy and the child/ young person him/herself. No decision about any aspect of care should be made without full involvement of the child/young person and their family in the decisionmaking process (18). In our study, the respondents reported that children with cerebral palsy and their parents/carer were not involved in the care pathway development process. Moreover, no surveys were conducted of the children and their family members to assess their satisfaction with the care they received and identify their expectations and their concerns.

Based on the skills and competencies required to meet the operational objectives of managing a child with a chronic disability, periodic assessment of training needs of health care providers should be conducted. The training plan should be based on the gap between the current capabilities of the health workers and the required capabilities to achieve the objectives of care (19). Among the standards reported as totally or partially unmet at the hospital was the lack of a system to monitor the training and supervision needs of care providers for children with cerebral palsy and demonstrate that

\begin{tabular}{|c|c|c|c|}
\hline Care item & $\begin{array}{c}\text { Not satisfied } \\
\text { No. }(\%)\end{array}$ & $\begin{array}{c}\text { Uncertain } \\
\text { No. (\%) }\end{array}$ & $\begin{array}{c}\text { Satisfied } \\
\text { No. (\%) }\end{array}$ \\
\hline Waiting time & $25(27)$ & $50(58)$ & $13(15)$ \\
\hline Waiting area & $56(63)$ & $27(31)$ & $5(6)$ \\
\hline Availability of facilities needed for your child & $22(23)$ & $55(64)$ & $11(13)$ \\
\hline Number of days where services are available to you & $3(2)$ & $54(62)$ & $31(36)$ \\
\hline Cost of services & $5(5)$ & $27(31)$ & $56(64)$ \\
\hline Doctor listens carefully to what you say & $8(8)$ & $48(55)$ & $32(37)$ \\
\hline Enough time to discuss problems & $13(14)$ & $46(53)$ & $29(33)$ \\
\hline Adequate explanation about your child & $12(13)$ & $52(60)$ & $24(28)$ \\
\hline
\end{tabular}




\begin{tabular}{|c|c|c|c|c|}
\hline \multirow[t]{2}{*}{ Characteristic } & \multirow[t]{2}{*}{ No. } & \multicolumn{2}{|c|}{ Caregivers' satisfaction percentage score } & \multirow[t]{2}{*}{ P-value ${ }^{\mathrm{a}}$} \\
\hline & & Min-Max & Mean (SD) & \\
\hline Level of education & & & & 0.133 \\
\hline Illiterate/read and write & 39 & $27.78-94.44$ & $59.40(17.39)$ & \\
\hline Primary school & 20 & $16.67-83.33$ & $56.39(20.25)$ & \\
\hline Secondary school & 22 & $27.78-77.78$ & $50.76(13.64)$ & \\
\hline University & 7 & $0.0-83.33$ & $45.24(24.73)$ & \\
\hline Marital status & & & & 0.859 \\
\hline Married & 80 & $0.0-94.44$ & $55.76(18.30)$ & \\
\hline Divorced & 4 & $38.89-72.22$ & $51.39(14.61)$ & \\
\hline Widowed & 4 & $33.33-83.33$ & $52.78(22.45)$ & \\
\hline Working status & & & & 0.136 \\
\hline Housewife & 80 & $0.0-94.44$ & $54.51(18.20)$ & \\
\hline Employed & 8 & $44.44-88.89$ & $64.58(15.97)$ & \\
\hline
\end{tabular}

${ }^{a} \mathrm{P}<0.05$ was considered statistically significant.

$S D=$ standard deviation.

they are acted upon and actively promoted. In addition, there is no system to ensure that these training and supervision needs and requirements are incorporated into the hospital development plans.

A report by the care quality commission in the United Kingdom in 2012 described the experiences of stakeholders and administrative staff about how services are provided to children with disabilities and their families (20). They reported generally negative experiences, particularly concerning coordination of services, their involvement in decisions and in the delivery of care, and the general quality of care provided. Moreover, they considered that health care action plans were inconsistent, so people using services had different experiences depending on the service they got.

High standards for documentation and management of health care records are consistent with current best practice requirements in any health care organization. A system should be in place to audit health care records and report results. Facility/service managers are responsible for ensuring that requirements of this policy are disseminated and implemented in their hospital, department or service. Moreover they must ensure that health care personnel within their facility or service have timely access to paper-based and electronic health care records. The health care record is a documented account of a patient/client's: history of illness; health care plan/s; health investigations and evaluations; diagnosis; care; treatment; progress; and health outcome for each health service intervention or interaction. It serves as a basis for planning care and for communicating patients' conditions and treatments with other health care providers (21).

The senior managers in our study reported that, although there is a secure system that allows information to be recorded in and accessed from the child's care record, the system lacks child diagnostic and assessment information that allows any changes to be detected. Moreover, our review of the child health records showed that most items on our checklist were not recorded, including medical and developmental histories, how the diagnosis was reached, structured care plan, medication decisions, specific goals of care, admission information and outcome measures. This finding is in contrast to the results of a study in California (22) that reviewed the service system delivered to children and young people with special needs and reported the health records were considered adequate. Nevertheless, they recommended that all families be able to receive a copy of the health record of their children whenever needed.

One of the basic measures of quality improvement in health care is to monitor the process of care and identify any deviation from the recommended care. Reasons for deviations should be specified and discussed, action taken and recorded, and the outcome documented and fed back to front-line staff (14). In our hospital, weakness in the documentation system, lack of record-keeping standards, and the absence of systems for recording, collating, analysing, reporting and acting upon changes are major barriers to quality improvement in the care of the children with cerebral palsy.

The responses of the 15 health care providers directly involved in the care of children with cerebral palsy showed that the standard of care was poor as indicated by the small number of providers who reported adherence to the recommended generic care standards of care. Specific areas that showed poor adherence were: recording a structured care plan; including the family in the decision-making process; giving enough information to the family about the diagnosis, plan of care and the anticipated outcome; and recording details of admissions to the hospital and the outcome of child care.

Parental involvement in the process of child rehabilitation is very important for both parents and 
professionals, and raises the level of parental satisfaction with the delivered care (23). Two community-based studies of family-centred services in Australia used the Measure of Processes of Care for Service Providers to assess the perceptions of parents/carers of the services provided $(24,25)$. The families rated "respectful and supportive care" highest and "providing general information" lowest.

Another study in Finland, which assessed the child health care from the perspective of both health care providers and users, indicated that providing written information about the child's condition, therapies and progression, and information about family group supports and community voluntary organizations that offer services were rated by both families and service providers as being poorly delivered (26). In a study in Switzerland, parents reported the overall level of care as fair to moderate but provision of information was the lowest rated area (27).

Parent/caregiver satisfaction with the care provided to their children is one of the outcome measures commonly used to assess the quality of health care (28). In our study, the mothers' satisfaction was very low for the waiting time and waiting areas as well as the availability of required facilities for their child's care. Moreover, they were dissatisfied with the amount of explanation they received about their child. The fact that there was no significant association between the mothers' characteristics and their satisfaction with the care provided indicates a suboptimal level of care from the perspective of all caregivers regardless of their background. In a study in Iceland, parents reported the overall therapy services as respectful, supportive and coordinated (29). Nevertheless, they felt that the information they received from professionals was insufficient. Similarly, a study in the Netherlands reported that parents of children with cerebral palsy did not feel adequately informed, especially about services for their children and family (30).
Similar to our study, 2 studies conducted in public hospitals and outpatient health care services reported low levels of patient satisfaction with care received with regard to attitudes towards professionals, quality of the surrounding atmosphere (including waiting areas), waiting time before being seen by a professional and quality of administrative services (31). They compared these services with those provided by the private sector and found better patient satisfaction in the private sector. They attributed this to the lower burden on professionals in the private sector, the availability of more facilities and more organized administrative services.

\section{Conclusions}

Our study shows that there is a wide gap between the actual provision of care for children with cerebral palsy and the recommended standards for the process of care of such children. Most mothers were not satisfied with several aspects of care provided to their children. Moreover, the documentation system in the hospital is poor.

A quality improvement plan is needed for care provision of children with cerebral palsy and their families, which includes continuous monitoring to identify variations in care and their causes, and to take action to address any problems. Periodic assessment of training needs of health care providers is important and the findings should be acted upon. Furthermore, a specific documentation system is urgently needed as part of the care pathways for children with cerebral palsy.

The family is the primary support for their child; it is therefore very important for health care providers to work in collaboration with families and to find ways to increase their participation in the care and rehabilitation plan of their child. As effective communication and information is key to quality standards for health and social care, strategies are needed to allow professionals enough time to listen carefully to the families' needs and to respond to their enquiries.

\section{Acknowledgements}

We thank Sara Fekry Maklad for her help in the collection of data from the children and their families.

Funding: None.

Competing interests: None declared.

\section{Qualité des soins apportés aux enfants atteints de paralysie cérébrale, Alexandrie (Égypte) Résumé}

Contexte : Évaluer la qualité des soins est devenu de plus en plus important pour les prestataires de soins de santé, les autorités de réglementation et les acheteurs de soins.

Objectifs : La présente étude a évalué la qualité des soins fournis aux enfants atteints de paralysie cérébrale pris en charge à l'hôpital universitaire pour enfants d'Alexandrie (Égypte).

Méthodes : Le personnel médical résident du département de neuropédiatrie $(n=15)$ responsable de la prise en charge des enfants atteints de paralysie cérébrale a rempli une liste de contrôle structurée visant à mesurer leur observance des normes de soins génériques. Les dossiers médicaux de 84 enfants atteints de paralysie cérébrale traités dans cet hôpital ont été examinés à l'aide de la même liste de contrôle. Une autre liste de contrôle a été remplie par le responsable de l'unité de neuropédiatrie, par le directeur médical de l'hôpital, par le responsable de la médecine physique et l'infirmière en chef 
afin d'évaluer l'observance des procédures et des normes d'amélioration des services. Des entretiens en face-à-face ont été conduits avec les soignants et les parents des enfants à l'aide d'un questionnaire de satisfaction clients.

Résultats : Sur la base de ce qui a été rapporté par les prestataires de soins de santé, la plupart ne se conformaient pas aux pratiques recommandées pour les soins apportés aux enfants atteints de paralysie cérébrale. L'examen des dossiers médicaux a également démontré le non-respect des normes. Le score de satisfaction total moyen des parents/soignants était de $55,43 \%$ (ET 18,16). La satisfaction était particulièrement basse eu égard au temps d'attente, aux salles d'attente et à la disponibilité d'établissements compétents pour la prise en charge de leurs enfants.

Conclusions: Il existe un écart important entre les soins fournis actuellement aux enfants atteints de paralysie cérébrale et les normes recommandées. De plus, le système de documentation de l'hôpital n'est pas performant. Un plan d'amélioration de la qualité est requis pour la prestation de soins apportés aux enfants atteints de paralysie cérébrale.

$$
\text { جودة الرعاية المقدمة إلى الأطفال الذين يعانون من الشلل الدماغي، الإسكندرية، مصر الوشي، هيام عبد الغني، طارق عمر، سامية أحمد }
$$$$
\text { الخلفية: تزايدت أهمية تقييم جودة الرعاية بالنسبة لمقدمي الرعاية الصحية والجهات التنظيمية ومشتري هذه الرعاية. }
$$

الأهداف: هدفت هذه الدراسة إلى تقييم جودة الرعاية المقدمة إلى الأطفال المصابين بالشلل الدماغي في مستشفى الأطفال بجامعاتهة الإسكندرية،

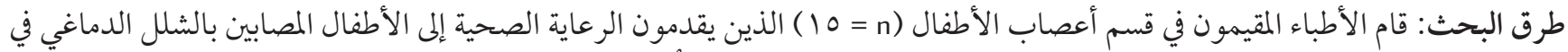

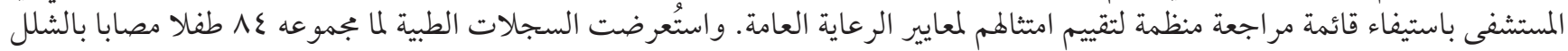

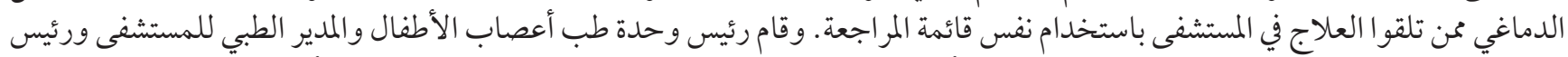

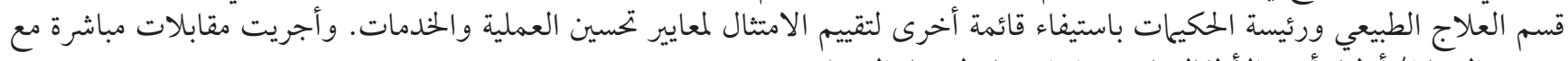
مقدمي الرعاية/ أولياء أمور الأطفال باستخدام استبيان لمانيفاء لرضاء العميل.

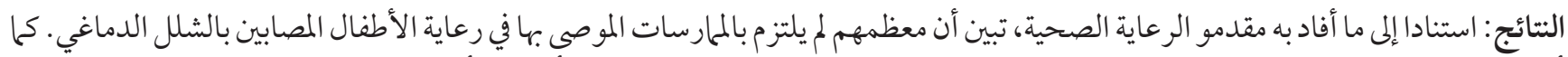

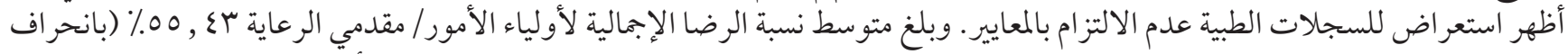

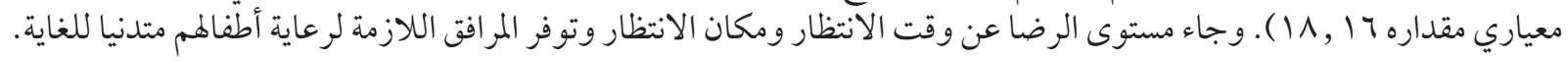

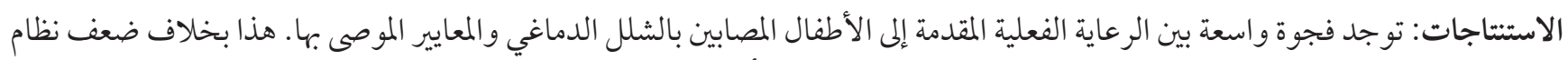

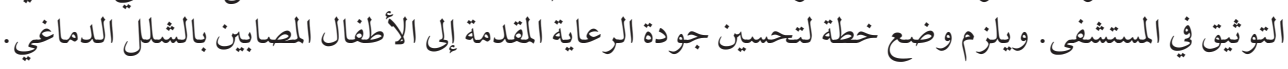

\section{References}

1. Cans CH, De-La-Cruz J, Mermet M. Epidemiology of cerebral palsy. Paediatr Child Health. 2008; 18(9):393-8.

2. Himmelmann K, Hagberg G, Beckung E, Hagberg B, Uvebrant P. The changing panorama of cerebral palsy in Sweden. IX. Prevalence and origin in the birth-year period 1995-1998. Acta Paediatr. 2005 Mar;94(3): 287-94.

3. Cans C, Guillem P, Fauconnier J, Rambaud P, Jouk PS. Disabilities and trends over time in a French county, 1980-91. Arch Dis Child. 2003 Feb;88(2): 114-7.

4. McCullough N, Parkes J, Kerr C, McDowell BC. The health of children and young people with cerebral palsy: a longitudinal, population-based study. Int J Nurs Stud. 2013 Jun;50(6):747-56.

5. Blair E, Watson L. Epidemiology of cerebral palsy. Semin Fetal Neonatal Med. 2006 Apr;11(2):117-25.

6. Odding E, Roebroeck ME, Stam HJ. The epidemiology of cerebral palsy: incidence, impairments and risk factors. Disabil Rehabil. 2006 Feb 28;28(4):183-91.

7. El-Tallawy HN, Farghaly WM, Shehata GA, Metwally NA, Rageh TA, Abo-Elfetoh N. Epidemiology of cerebral palsy in El-Kharga District-New Valley (Egypt). Brain Dev. 2011 May;33(5):406-11.

8. El-Tallawy HN, Farghaly WM, Shehata GA, Rageh TA, Metwally NA, Badry R, et al. cerebral palsy in Al-Quseir City, Egypt: prevalence, subtypes, and risk factors. Neuropsychiatr Dis Treat. 201407 8;10:1267-72.

9. Reilly S, Skuse D. Characteristics and management of feeding problems of young children with cerebral palsy. Dev Med Child Neurol. 1992 May;34(5):379-88.

10. Pousada M, Guillamon N, Hernandez-Encuentra E, Munoz E, Redolar D, Boixados M, et al. Impact of caring for a child with cerebral palsy on the quality of life of parents: a systematic review of the literature. J Dev Phys Disabil. 2013; 25(5): 545-77.

11. Lim Y, Seer M, Wong CP. Impact of cerebral palsy on the quality of life in patients and their families. Neurol Asia. 2009; 14(1): 
27-33.

12. Royal College of Nursing. Measuring for quality in health and social care. An RCN position statement. 2009 (www.rcn.org.uk/ professional-development/publications/pub-003535, accessed 24 January 2018).

13. Agency for health care research and quality. Understanding quality measurement. 2012 (www.ahrq.gov/professionals/quality-patient-safety/quality-resources/tools/chtoolbx/understand/index.html, accessed 24 January 2018).

14. Health Improvement Scotland. Standards for integrated care pathways for child and adolescent mental health services. Final standards. 2011 (www.healthcareimprovementscotland.org/programmes/mental_health/icps_for_mental_health/child_and_adolescent_services.aspx, accessed 24 January 2018).

15. Jackson KE, Krishnaswami S, McPheeters M. Unmet health care needs in children with cerebral palsy: a cross-sectional study. Res Dev Disabil. 2011 Nov-Dec;32(6):2714-23.

16. Greenstein C, Lowell A, Thomas DP. Improving physiotherapy services to Indigenous children with physical disability: Are client perspectives missed in the continuous quality improvement approach? Aust J Rural Health. 2016 Jun;24(3):176-81.

17. Lindly OJ, Chavez AE, Zuckerman KE. Unmet health services needs among US children with developmental disabilities: Association with family impact and child functioning. J Dev Behav Pediatr. 2016 Nov/Dec;37(9):712-23.

18. Lahati B, Fairhurst $\mathrm{CH}$, Horridge K. Care pathway for children and young adults with cerebral palsies. British Academy of Childhood Disability. September 2012 (www.bacdis.org.uk/policy/guidelines.htm, accessed 24 January 2018).

19. Rossati L. Health and training needs assessment. Global health toolkit No. 6. Royal College of Obstetricians and Gynaecologists. 2014 (www.rcog.org.uk/globalassets/documents/global-network/global-health-toolkits/needs-assessment.pdf, accessed 24 January 2018).

20. Care Quality Commission. Health care for disabled children and young people. Special review. 2012:28-9. (www.cqc.org.uk/sites/ default/files/documents/health_care_for_disabled_children.pdf, accessed 24 January 2018).

21. Health care records - documentation and management (Document number PD2012_069). NSW Government. 2012 (www.health. nsw.gov.au/policies/, accessed 24 January 2018).

22. Smith K, Soman L, Duenas J, Garro N, Burke M, Robinson T, et al. California's Service System for children and youth with special health care needs. Analysis and recommendations for a service system that works for children and families. California: California's Service System; 2009 (www.lpfch.org/sites/default/files/field/publications/servicesystemreport.pdf)

23. Galil A, Bachner YG, Merrick J, Flusser H, Lubetzky H, Heiman N, et al. Physician-parent communication as predictor of parent satisfaction with child development services. Res Dev Disabil. 2006 May-Jun;27(3):233-42.

24. Raghavendra P, Murchland S, Bentley M, Wake-Dyster W, Lyons T. Parents' and service providers' perceptions of family -centred practice in a community-based, paediatric disability service in Australia. Child Care Health Dev. 2007 Sep;33(5):586-92.

25. Dyke P, Buttigieg P, Blackmore AM, Ghose A. Use of the measure of process of care for families (MPOC-56) and service providers (MPOC-SP) to evaluate family-centred services in a paediatric disability setting. Child Care Health Dev. 2006 Mar;32(2): 167-76.

26. Jeglinsky I, Autti-Rämö I, Brogren Carlberg E. Two sides of the mirror: parents' and service providers' view on the family -centredness of care for children with cerebral palsy. Child Care Health Dev. 2012 Jan;38(1):79-86.

27. Seliner B, Latal B, Spirig R. When children with profound multiple disabilities are hospitalized: A cross-sectional survey of parental burden of care, quality of life of parents and their hospitalized children, and satisfaction with family-centered care. J Spec Pediatr Nurs. 2016 07;21(3):147-57.

28. Hayles E, Harvey D, Plummer D, Jones A. Focusing on families' experiences of health care: choosing a qualitative research design. J Dev Disabil. 2015;21(2):110-8.

29. Arnadottir U, Egilson ST. Evaluation of therapy services with the Measure of Processes of Care (MPOC-20): The perspectives of Icelandic parents of children with physical disability. J Child Health Care. 2012 Mar;16(1):62-74.

30. Alsem MW, Verhoef M, Gorter JW, Langezaal LCM, Visser-Meily JMA, Ketelaar M. Parents' perceptions of the services provided to children with cerebral palsy in the transition from preschool rehabilitation to school-based services. Child Care Health Dev. 2016 07;42(4):455-63.

31. Agha S, Do M. The quality of family planning services and client satisfaction in the public and private sectors in Kenya. Int J Qual Health Care. 2009 Apr;21(2):87-96.

32. Chahal H, Sharma RD, Gupta M. Patient Satisfaction in Public Outpatient Health Care Services. J Health Manag. 2004;6(1):23-45. 